\title{
IMPACT INVESTMENT OF PROJECT FINANCING: OPPORTUNITY FOR BANKS TO PARTICIPATE IN SUPPORTING GREEN ECONOMY
}

\author{
Khaliun GANBAT ${ }^{\mathbf{1}}$, Inessa POPOVA ${ }^{\mathbf{2}}$, Ivan POTRAVNYY ${ }^{3}$ \\ ${ }^{1}$ Plekhanov Russian University of Economics, Mongolia \\ ${ }^{2,3}$ Plekhanov Russian University of Economics, Russia \\ Corresponding authore-mail: ecoaudit@bk.ru
}

\begin{abstract}
The article analyses impact investment of project financing. Companies' own funds, own funds of the consortium members, the company's own resources and budget funding, own funds of the company on the basis of a production sharing agreement, borrowed funds; the funds raised by the bond issue are all considered as the project financing sources in the natural resource field. The purpose of this article is to consider various opportunities to support environmentally oriented projects in the framework of project financing, including through attracting funds of banks for the development of "green" economy. The role of banks and the banking sector in supporting environmentally and socially oriented projects is analysed. The experience of banks in Asia, Europe and the United States in terms of "green" economy projects is shown. Moreover, environmental and social risks, and impact of a project, the project compliance with the norms and standards of responsible finance are all considered in this article.

Classification of environmental projects with the purpose of project financing is proposed, and also the scheme of interaction between stakeholders is shown, including banks, in the implementation of projects reducing greenhouse gas emissions. Furthermore, impact investment in financing projects with the participation of banking sector is analysed and justified on the example of such countries as Mongolia, Russia, Japan, the United States and others. Evaluation procedures and the selection of projects for social investment purposes are shown in the article, including the measures of supporting banks for the project implementation in the field of "green" economy. The following research methods are considered: systematic analysis, environmental economic analysis environmental auditing, statistical methods for evaluating the costs and benefits from implementing environmentally oriented projects, methods of assessment of damage from environmental pollution, etc.
\end{abstract}

Keywords: Bank participation, environmental economics, "green" economy, impact investment.

\section{INTRODUCTION}

Project financing is a special form of financing projects in which the assets and liabilities of investors, not related to the project, are legally separated from the project, while the return on capital is ensured not with assets of the borrower but by the project future cash flows. One of the project financing features is the ability to 
use a wide range of sources, means and methods of financing investment projects, including bank loans, issues of shares, shares in the capital stock, bonds, lease, own funds, etc. Private loans for project financing are provided by two major sources: commercial banks and bond investors.

In today's reality, business or project is more successful, if its leader considers the socially significant achievement as the priority goal. Obviously, social impact investing - is a more general concept than a specific investment strategy. The main criterion here is the desire to make an investment in the project that brings tangible social benefits in addition to the economic benefits (Bayandina \& Voronin, 2015). However, this type of investment is far from a clear example of charity and follows the classical principles of investment project management, carried out in developing countries. A good example of a successful impact investment is the JP Morgan, which has repeatedly stressed the importance of impact investment in its corporate mission. In this area, the company chose the course of a return of investment in the social sphere and in the sphere of environmental protection. In general, the JP Morgan's cooperation program with the African Agricultural Capital Fund in the long term requires support for 250 thousand farmers from all agricultural areas in East Africa. Social investors, in comparison with the traditional ones, while making investment decisions, consider not only the expected financial results and the level of risk, but also the expected social impact. High efficiency in solving social problems can balance low profitability. At the same time impact investors can rely on a number of benefits.

Firstly, it is a fast-growing market. According to the forecast of social investors' global network (Global Impact Investment Network - GIIN) and JP Morgan, in comparison with the year 2015, there will be a $20 \%$ growth of total investment of 125 leading social investors in 2016.

Secondly, almost all countries face the necessity of permanent reduction in budget expenditures. It encourages governments to transfer their social functions by outsourcing private companies that can provide more efficient use of funds and ensure better quality of social services. In addition, private providers of social services can be more creative being in compliance with the established quality standards by the country, and also their services are more focused on the needs of specific customers.

Thirdly, the principle of "payment for social results" in country's social policy is getting replaced with the principle of "payment for services". This approach reduces the risk of impact investors due to their diversification.

Fourthly, some social investments, such as microfinance, provide a good financial return on the average market level.

The volume of impact investment market can be imagined, based on the following facts: currently 1,276 investment funds and other institutions that manage assets totalling more than $\$ 45$ billion, signed the Principles of Responsible Investment of the United Nations, accepting the responsibility of taking into account environmental, social and governance factors while making any corporate decision. The fact that current global trend is the transition to the principles of "green" economy, which is closely related to impact investment, should be noted. The United Nations Environment Program (UNEP) defines as "green" economy the 
economy that increases welfare of people and ensures social equity while significantly reducing environmental risks and its depletion (Towards a "green" Economy. - United Nations, 2011a). The transition to a "green" economy is associated with an increase in direct and related investments into environmental technologies, reduction and recycling waste, support of environmental business activities in the sectors of new technological discoveries, creation of conditions for raising capital on the market for environmental goods and services, creation of additional "green" work places (Viehohh \& Theis, 1997). Under these conditions the measures of market formation of "green" investment products and encouraging banks, mostly the state ones, for the implementation of international rules of lending and the development of "green" financial products are taken in Russia". Moreover, a fund for direct investments in share capital with high environmental component, in particular, on the basis of the Russian Direct Investment Fund has been created.

Social investments are generally aimed at improving people's life, environment recovery, supporting environmentally and socially oriented projects and programs (Potravnyy, Gassy, Chernogradsky, \& Postnikov, 2016). In recent years, considerable experience of impact investment is accumulated in the banking sector of economy (Akchurina, 2008).

\section{SOURCES OF PROBLEM FORMULATION OF SOCIAL INVESTMENT IN PROJECT FINANCING AND CLASSIFICATION OF ENVIRONMENTAL PROJECTS}

Currently, there are various sources of project financing. For example, A. Yu. Nikulina considers the following sources of investment in the project of development of oil and gas in the Arctic: company's own funds, own funds of the consortium members and government funding, own funds of the company on the basis of a production sharing agreement, borrowed funds and the funds raised by the bond issue (Nikulina, 2016). International banking community is increasingly taking part in the integration process of economic development interests and environmental sanitation. This is reflected in the expansion of investment lending of environmentally oriented entrepreneurial activity, supporting projects on solving ecological problems and reducing greenhouse gas emissions. Certain prospects of bank participation in supporting environmentally significant projects related to the implementation of the UN Framework Convention on Climate Change (Paris, 2015), which is reflected in the activities of the "Green" Climate Fund. With regard to the subject of "low-carbon" development and managing the reduction of greenhouse gas emission the role of banking sector in this process might look like in Fig. 1 (created by the authors).

\footnotetext{
${ }^{1}$ Resolution of IV Russian Congress on Environmental Protection. Moscow, 2013 (available at http://www.mnr.gov.ru/regulatory/detail.php?ID=131936).
} 


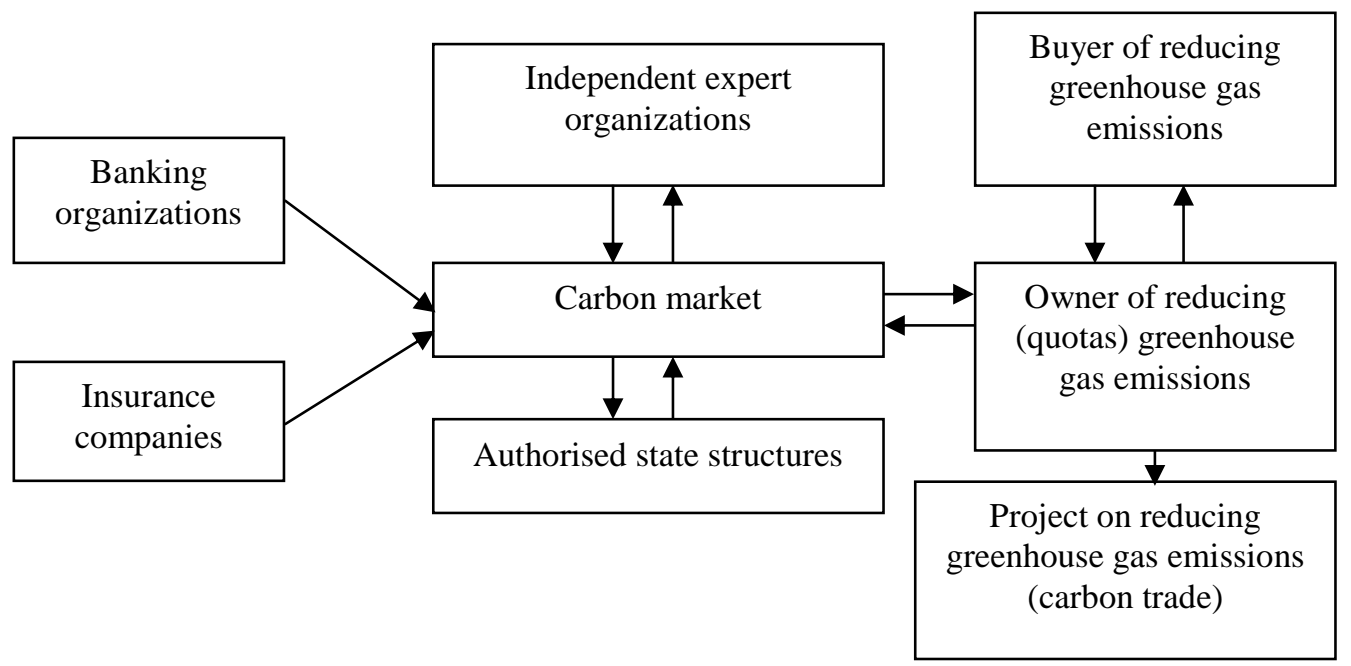

Fig. 1. Scheme of stakeholders' interaction in the implementation of projects to reduce greenhouse gas emissions.

Recently, based on the world practice, the capital of commercial banks is an important source of financing environmental activities (along with the state budget, own funds of enterprises, leasing companies, environmental funds, insurance companies and international financial institutions). Important areas of impact investment also include elimination projects of accumulated environmental damage, supporting projects in developing Arctic territories for traditional nature use, developing organic farming projects, eco-tourism and others.

It should be noted that investment environmental projects could be divided into two groups: a) environmental projects, b) technological projects with environmental benefits.

Fig. 2 shows the classification of environmental projects for project financing purposes (created by the authors).

The positive effect of implementing such projects is achieved by protecting atmosphere and water basin from pollution, reducing waste area, decreasing land pollution, reducing greenhouse gas emissions, eliminating accumulated ecological damage, improving living conditions of the population. In 1999, the Conference Board of American Analytical Organization estimated that companies implementing the concept of social responsibility have $9.8 \%$ higher return on invested capital, $3.55 \%$ bigger income from assets and profit higher by $63.5 \%$ than their competitors who ignore it (Global Reporting Initiative, 2000). 


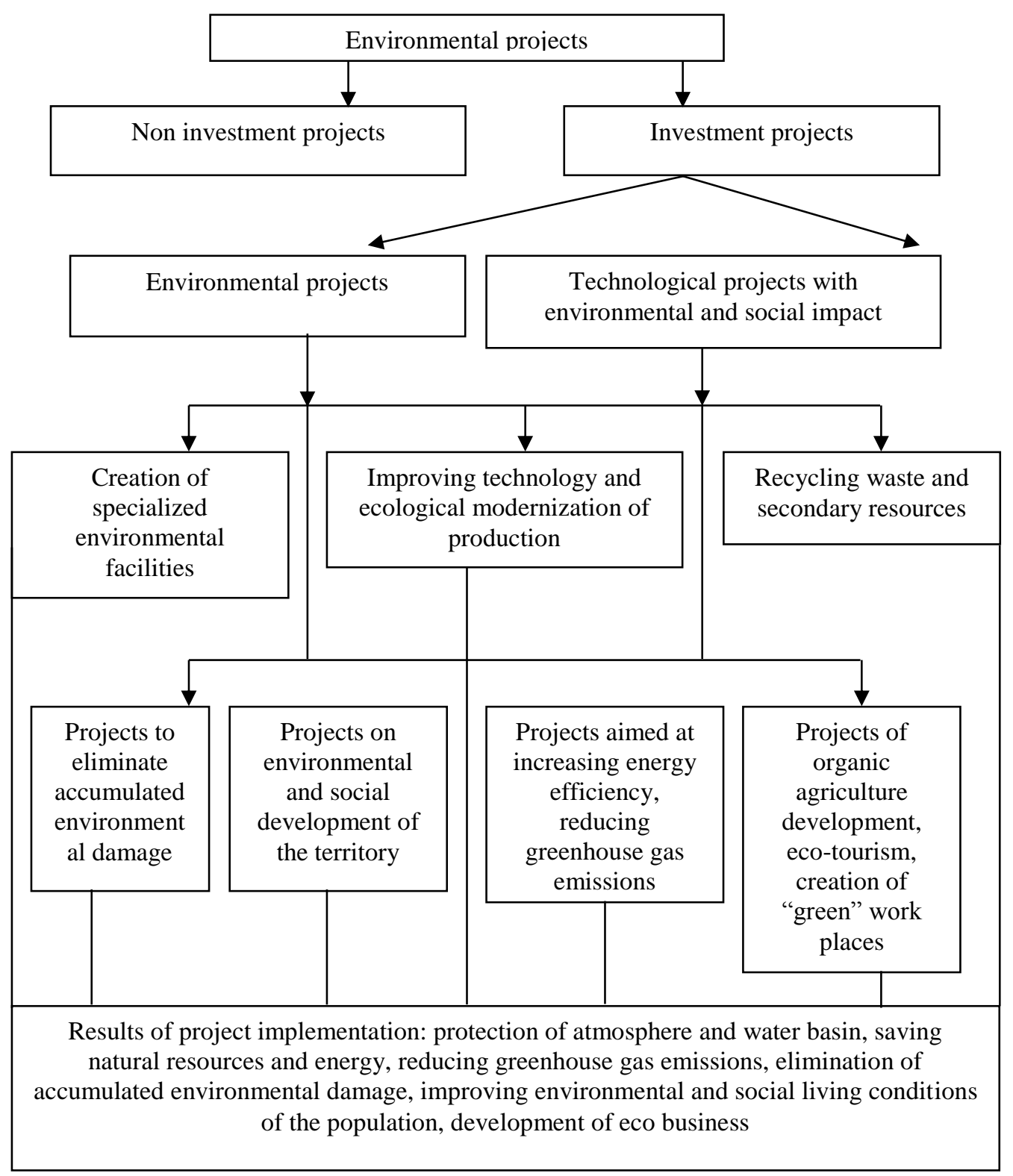

Fig. 2. Classification of environmental projects for project financing purposes.

\section{RESULT ANALYSIS. POSSIBILITY AND EXPERIENCE OF BANK PARTICIPATION IN FINANCING ENVIRONMENTAL PROJECTS}

There are different points of view regarding the importance and necessity of project financing by commercial banks, which according to experts is considered as the most risky activity (Schmidt, 1999). However, financing a project for 5 to10 years, the bank forms a long-term stable customer base with great potential of selling other banking services and products to the customer. Thus, this type of activity may become a great competitive advantage for banks to attract the best regional customer, and get a higher yield on debt instruments, especially in the presence of upside. This means the ability to earn on the growth of the company's 
market capitalization, for example by buying call options at the current market price and selling at the future market value of a company's minority stake. Thus, project financing for banks is a long-term lending to finance investment projects and the main source of repayment of loan principal is the cash flow that is generated by the project in the future, after the successful completion of project investment phase or after the successful market entry.

It should be noted that the following European banking institutions are active on the market of environmental services: Deutsche Bank, Landesbausparkasse (LBS), Credit Suisse, Bayerische Landesbank, Allianz Versicherungs AG, Landesgirokasse Stuttgart, Schweizerischer Bankverein Zuerich, Schweizerischer Kreditanstalt (SKA), and others (Silva, 1999). The environmental management system is implemented, for example, in Landesgirokasse Stuttgart, Frankfurter Sparkasse, Deutsche Bank, Bayerische Landesbank, and also in such Swiss banks as Credit Suisse Group CSG and UBS (Schierenbeck \& Seidel, 2000). German Deutsche Bank began impact investment activity in 2000, by starting a housing program, financing "green" projects and releasing of Social Impact Bonds, which are bonds for projects oriented to the environmental and social impact (Silva, 1999).

We know that in times of economic crisis, profit maximization and cost reduction are the primer objects, and only after that comes environmental protection. However, there are still positive examples of financial institutions, such as the China Development Bank and the Brazilian Development Bank that despite the crisis situation in the world market continue supporting projects aimed at environmental protection, energy savings and energy efficiency. However, the activity of financial institutions formally has no direct impact on the environment and quality of life. Nevertheless it is a stimulus for other market participants to take environmental and social responsibility through their investment decisions. As financial institutions, commercial banks are able to create new products and services that promote environmental sustainability and social and economic development. Of course, banks can also directly invest in this area. In our opinion, a responsible approach to investing is also attractive from a commercial point of view, because it improves management quality of both financial and non-financial risks. In Russia, for example, the Bank of Development and Foreign Economic Affairs (Vnesheconombank, www.veb.ru) participated in financing 24 projects with total cost of 440 billion rubles, aimed at the improvement of the efficiency of usage of natural resources, ecological protection and improvement of environment, with the volume of 312 billion rubles of the bank's participation, and also 27 projects of increasing energy efficiency with total cost of 538 billion rubles, 300 billion rubles of which was the share of Vnesheconombank.

As an example, let us consider the environmental reporting of BBVA banking group. Banco Bilbao Vizcaya Argentaria S.A. is a financial institution with the head office in Spain. The group participates in the share capital of a number of companies in Spain and abroad, as well as of its branches. This Bank supports sustainable development through the implementation of various projects. In 2006, there was a substantial progress in considering social and environmental aspects in financing projects. The adoption of the Equator Principles has obliged the bank to improve its social and environmental risk management system, which was implemented in 
the Department of Structured Finance. Such factors as a) the environmental policy/ environmental management system; b) the maintenance of bank's environmental reporting; c) business opportunities; g) project financing; d) the presence of a developed system to evaluate environmental efficiency of projects are considered in the evaluation of corporate responsibility rating assigned to BBVA by specialized agencies.

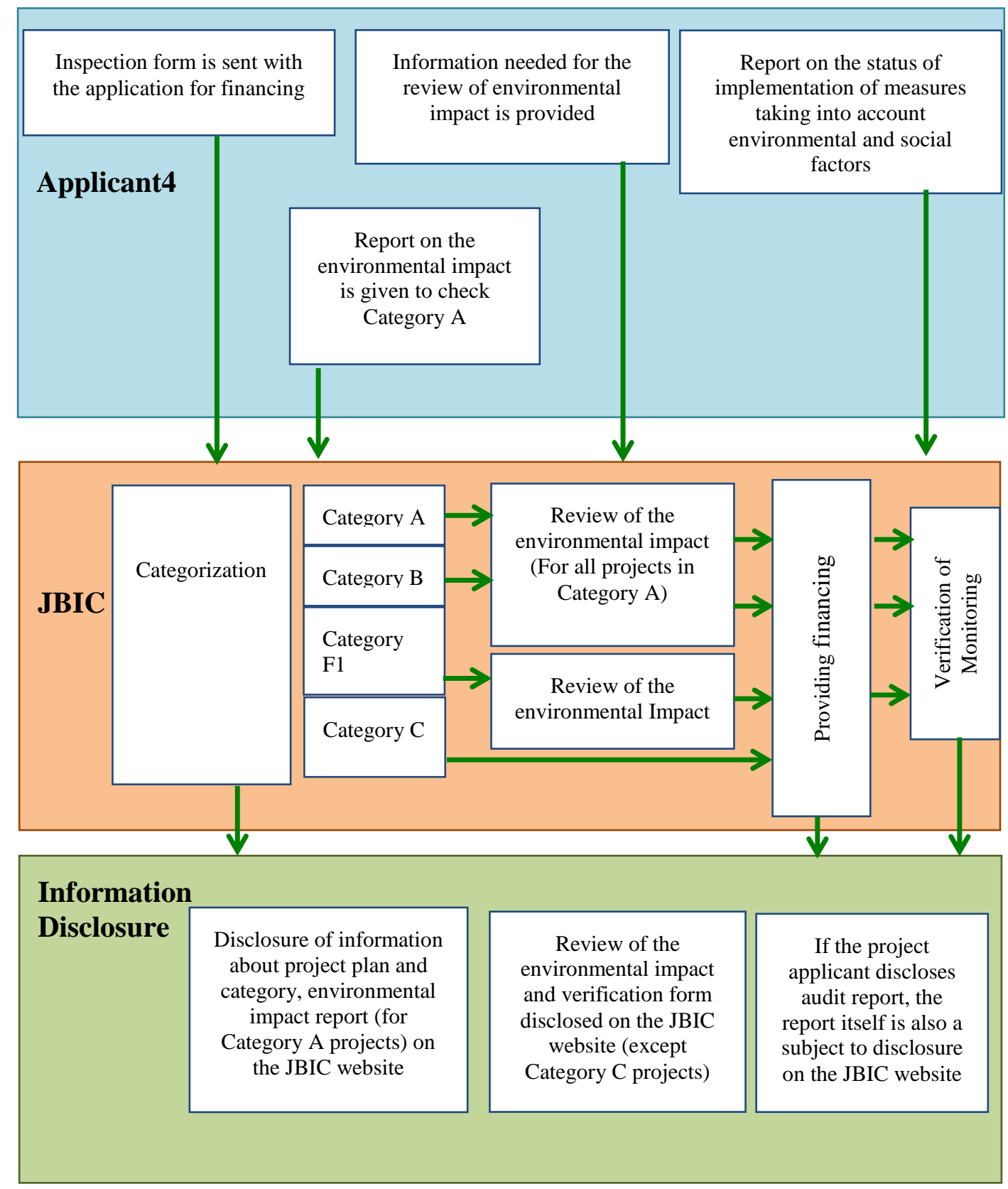

Fig. 3. The project evaluation process by Japan Bank for International Cooperation, taking into account social and environmental risks. 


\section{IMPACT INVESTMENT IN SOUTH ASIA}

India has become one of the first Asian countries with impact investors. So, Aavishkaar Indian Micro Venture Capital Fund was established in 2002 to provide financial and administrative support for rural entrepreneurs. During this period, the state program was developed to financially support social enterprises. At present, in India there are at least three major federal sources of funding social enterprises: Council for the Development of Agricultural Technology (CAPART), Bank for Small Business Development of India (SIDBI), National Fund of Innovation (NFI). CAPART operates under the Ministry of Agriculture and provides funds for rural development and agriculture. SIDBI was established to finance small and micro enterprises, which contribute to the process of economic growth, creating jobs and balanced regional development. NFI provides organizational and infrastructural support for environmental innovation, helping them to reach self-sufficiency.

A very similar system of financial support for small and medium-sized enterprises was developed in Malaysia. The Thai government has also established the National Fund for the rural and urban development to encourage investment, employment and prosperity in the country. Singapore works in a way, creating a Social Innovation Park (SIP), a non-profit organization, that is an incubator for social entrepreneurs and innovators (Table 1).

Table 1. List of Major Social Enterprises in South Asia (created by the authors)

\begin{tabular}{|c|c|c|c|}
\hline Clean energy & Education & Ecology & Fair Trade \\
\hline $\begin{array}{c}\text { D. light (India), } \\
\text { Rural Light } \\
\text { (Philippines), } \\
\text { Selco (India) }\end{array}$ & $\begin{array}{c}\text { O School } \\
\text { (Singapore), } \\
\text { Let it Help } \\
\text { (Philippines) }\end{array}$ & $\begin{array}{c}\text { Social Enterprise Com- } \\
\text { Win Inc. (South Korea) }\end{array}$ & $\begin{array}{c}\text { Fair Trade Company } \\
\text { (Japan) }\end{array}$ \\
\hline & & $\begin{array}{c}\text { Eco Wise Waste } \\
\text { Management Pvt. Ltd. } \\
(\text { India })\end{array}$ & $\begin{array}{c}\text { Barefoot (Sri-Lanka), } \\
\text { Doi Tong (Thailand), } \\
\text { Organic Tea (Bangladesh) }\end{array}$ \\
\hline
\end{tabular}

An important event for the Asian impact investment market was the creation of Impact Investment Exchange in 2013, which was designed to become a platform for attracting investment in social business. At the same time a prerequisite for working with the exchange is to have an elaborate strategy to achieve social performance or concrete already achieved results, an efficient management structure, compliance with the requirements of the investor on the transparency and liquidity. However, not all social enterprises in South Asia comply with these standards (Asian Development Bank, 2014).

\section{“Green" Investment in Commercial Banks}

In October 2008, the project "Green Economic Initiative" (http://web.unep.org/greeneconomy/-Official website of United Nations Environment Program) was launched in the framework of the United Nations Environment Program (UNEP). In accordance with the initiative, mobilization and 
re-orientation of the global economy for investment in clean technologies and "natural" infrastructure such as forests and soils is the best choice for real growth, combating climate change and increasing an employment in the XXI century. In this regard, many financial development institutions and commercial banks, despite the unstable economic situation in the world, support projects oriented at environmental protection, energy saving and efficiency. In 2010, the Banking Commission was created in the banking sector UNEP in order to promote the initiatives mentioned above. In 2011, UNEP prepared a Guide to a Sustainable Development of the banking sector (United Nations, 2011b). As of May 2016, there are 200 banks of more than 50 countries in the Banking Commission, including Russian Vnesheconombank and Golomt Bank of Mongolia (United Nations, 2011a).

Banks - members of the Banking Commission respect and care natural resources, finding ways to reduce costs, strengthen relationships with customers, who hold similar views on sustainable development and environmental security.

Financial development institutions invest highly in the implementation of initiatives aimed at the development of "green" economy. They are:

- China Development Bank;

- The Bank of Social and Economic Development of Brazil;

- State Corporation "Bank of Development and Foreign Economic Affairs" (Vnesheconombank);

- "Green" Investment Bank of the UK;

- Japan Bank of International Cooperation and others.

The main activities of the above-mentioned financial institutions towards the transition to a "green" economy are: a) ecological and social assessment of project financing; b) creation of "green" offices; c) financing "low-carbon development" projects; g) supporting energy conservation and sustainable development projects; d) supporting development of alternative energy projects; e) funding projects of environmental infrastructure creation.

The best practices of foreign commercial banks in the implementation of sustainable development principles are of particular interest. Analysts of the American edition "Bank Technology News" on the basis of their own investigations have identified the four most "green" American banks: "First Green Bank", "Huntington National Bank", "Citigroup", "U.S. Bank".

\section{China Development Bank}

This bank in accordance with the internal Guidelines for Project Evaluation in the field of energy saving and environmental protection severely restricts financing projects with high-energy consumption and high pollution levels. In general, there are a number of internal regulations in the bank governing the investment activity of China Development Bank (CDB) in the field of energy efficiency, reduction of emissions of harmful substances into the atmosphere and environmental protection:

- Investment plan in wastewater treatment;

- Investment plan in reducing emissions of harmful substances into the atmosphere; 
- The annual work plan of the BRC on financing environmental projects, energy saving and emission reduction, and others.

China Development Bank supports renewable energy projects of hydroelectric power, wind power, solar power industry. By the end of 2011, the total volume of credit investments of the bank in hydropower projects totalled 375.9 billion Yuan, which was $25 \%$ of the total investment in hydropower and covered all major projects. In projects of wind energy, solar energy and bioenergy collectively 114.9 billion Yuan were allocated, which was more than one third of all investment in this sector.

\section{Russian State Corporation "Bank of Development and Foreign Economic Affairs"}

In 2011, Program of Monitoring and Implementation of Investment Projects carried out with the participation of Vnesheconombank was developed in Russia. Monitoring the implementation of investment projects included technical, financial monitoring and monitoring investment projects. In 2012, an evaluation methodology of Vnesheconombank's socio-economic efficiency was developed with a range of economic, fiscal, social and environmental efficiency indicators; the calculation was based on monitoring results of investment projects and contracts financed by Vnesheconombank. Management of social and environmental impacts of Vnesheconombank's investment activity was carried out in the following areas: development projects in the field of innovation; development projects in the field of efficient use of natural resources and in energy efficiency. In Russia, the attraction of financial resources for projects of efficient use of natural resources and energy is difficult, because of the long payback period, high cost of credit and the lack of sufficient competence to examine programs in Russian credit institutions.

\section{Japan Bank for International Cooperation}

One of the main goals of the Japan Bank for International Cooperation is to achieve economic growth without causing harm to the environment and taking into account social factors. JBIC focuses on supporting nature conservation or environmental development projects and takes active measures to prevent global warming. In accordance with the "global development agenda", the Bank has formulated five main areas of its activity, naming them as the direction of sustainable development: a) global climate change; b) fight against AIDS; c) protection of water resources; g) energy issues; d) elimination of poverty. In accordance with the Guidelines of the Japan Bank for International Cooperation, that take into account environmental and social factors (Environmental Protection Manual), the bank confirms that the borrowers take appropriate measures to integrate environmental and social considerations in projects financed by the Japan Bank for International Cooperation. Prior to the financing, all projects are reviewed and categorized according to the level of potential environmental impacts. Then, a review of the environmental impact is done to validate the integration of environmental factors. After the financing, projects are monitored to assess the 
actual impact. Fig. 3 provides a diagram of the project financing in JBIC (made by the authors).

The project is assigned to one of the four categories (listed below) according to the degree of their environmental impact based on information provided by the project applicant.

Category A - projects with high risk of significant negative effects on the environment.

Category B - projects with a lower risk of negative effects on the environment than Category A projects.

Category $\mathrm{C}-$ projects with minimal risk of negative effects on the environment or without it.

Category F1 - project financing of JBIC provided to financial intermediary.

\section{"Green" bank in the United States - "First Green Bank"}

"First Green Bank" was established in the US in 2009. The main difference of the new financial institution was supposed to be the commitment to the ideals of environmental protection. The bank considers the conversion plans for building future headquarters with a zero energy balance, the concept of which is based on meeting all energy needs with low-cost, geographically accessible, clean and renewable energy sources.

\section{State Support for Banks in Financing Environmental Projects in Mongolia}

In Mongolia, project financing, in particular the investment of ecologically and socially oriented projects, still has a very narrow concept. There are 14 commercial banks in the country, the largest environmental project investors of which are the Trade and Development Bank, Golomt Bank and Khaan Bank. Moreover, since 2011, there has been operating a Bank of Development, which is fully state-owned, and its operations are mainly aimed at financing projects for the development of Mongolia, improvement of economic stability and the quality of life, and environment protection. The main financing areas are: a) innovative development; b) construction of new railways and highways; c) the Sainshand Industrial Complex; g) the project reducing air pollution in Mongolia, and d) the construction project of water treatment plant for steppe regions of the country.

The source of funding for the Bank of Development is Chinggis bond in the amount of 800 billion MNT or \$ 400 million issued in 2011. Moreover, companies that operate to solve environmental problems in the country are financed by the state funding within the Program of Support for Small and Medium-sized Enterprises by the Ministry of Nature. The main idea was to support the field of "green" development and tourism projects. Currently, the Bank has financed 2 environmental projects: the project of producing coal substitute - the new heating technology which will solve air pollution problem of Mongolia in winter, and the construction project of water treatment plant in Dornogobi aimag. It should be noted that environmental and social projects in the country are financed not only by local banks and government, but also by foreign banks. For example, the Trade and Development Bank of Mongolia in cooperation with the JBIC funded 12 projects 
in the amount of $\$ 4$ million, as part of a two-step loan project for small and medium business development and environmental protection. The Asian Development Bank financed 4 projects of agriculture and rural development in Mongolia.

One of the areas of supporting environmentally and socially significant projects in Mongolia can be the co-financed operation on the elimination of accumulated environmental damage due to the depletion of the resource base of mining companies and closing mine enterprise, which can be seen on the example of the "Erdenet" enterprise (Gengut, Alnykina, Davaakhuu, \& Potravnyy, 2015). However, there are a number of problems that banks face in financing environmental projects. Effective state support is of great importance to develop investment activity of banks, primarily by increasing the volume of state guarantee and extension of interest subsidies on investment loans. And the Government of Mongolia is currently working on it by implementing a Program of Supporting Financial Institutions involved in impact investment. According to the Ministry of Environment, the program will come into effect from year 2017.

\section{DEVELOPMENT OF FORMS AND METHODS OF SUPPORTING ENVIRONMENTALLY AND SOCIALLY ORIENTED PROJECTS}

Forms and methods of financing investment projects have significant differences and with this purpose the issue of shares, loan purchase, leasing, mortgage loans and etc. can be used. Each of these forms of financing has certain advantages and disadvantages. Therefore, any investment project should be carried out through impact assessment using different schemes and alternative forms of financing. For example, it is important to hold the right balance between long-term debt and equity capital, as the higher the leverage ratio is, the greater will be the amount paid on interest. Obtaining financial resources by issuing shares is one of the most common forms of financing investment projects. It is the preferred form of financing initial stages of large investment projects.

\section{CONCLUSION}

The following criteria are used to evaluate banks and other financial institutions during the selection and environmental justification of loan applications:

- Projects that support and enable integration of economic and environmental interests of development and realization of integrated environmental protection measures;

- Pojects and activities to reduce the consumption of materials, natural resources and raw materials that lead to low costs;

- Projects supporting the production of products with ecological purpose and environmental services and their promotion into the market;

- Projects that support managing of the demand through the cost pricing of environmentally friendly products and technologies;

- Projects aimed at strengthening the market for environmental responsibility and reducing environmental and economic risks; 
- Investment projects aimed at strengthening the capacity of environmental and economic growth in the future.

Taking into account the public opinion about banking activities of environmental protection, in our opinion, it is advisable to use "integrated reliability index", which takes into account the degree of support of the bank in environmental programs and interventions. Sponsorship of banks in the improvement of environment and holding ecological lottery, the raised funding which is directed to the preservation of rare species of animals, financial support for social "green" movement and others have significant effect on the overall image of the bank.

To objectively assess the bank there should be the following indicators based on its activities in the field of environmental protection:

1. The share of funds allocated for environmental purposes;

2. Liquidity ratios should be calculated taking into account the client's environmental obligations, while issuing the credit.

"Natur-Aktien Index" (Nax) was established to evaluate the effectiveness of environmentally oriented investments, which shows that these investments have achieved great success as compared with most of other funds and individual stocks. Analysis of market opportunities determines the direction of banking services diversification and the creation of new types of ecological services of banks. This is the flexible use of a wide range of banking products for financing environmental business. NERAX Eco indices can already be used to attract investment of socially responsible foreign funds to cooperate with Russian companies. Commercial banks, in addition to their classic operations, may invest in environmentally oriented projects that will allow them not only fulfil their social responsibility and thereby strengthen the confidence of present and future customers, but also manage their resources effectively.

\section{ACKNOWLEDGMENT}

The presented research was supported by the Russian Humanitarian Foundation, Project No. 1502-0014la, and Project No. 15-22-00303.

\section{REFERENCES}

Akchurina, N. M. (2008). The environmental and social factors in the Bank. Economics of nature management, 3, 55-68.

Asian Development Bank. (2014). Impact Investors in Asia: Characteristics and preferences for investing in Social Enterprises in Asia and the Pacific.

Bayandina, V. A., \& Voronin, D. M. (2015). Methods of analysis of investment projects for the purposes of the Bank project financing. Perm University Bulletin, 1(16), 57-63.

Gengut, I., Alnykina, E., Davaakhuu, N., \& Potravnyy, I. (2015). Management of Environment Cost in the Project: the Experience of Russia and Mongolia. Baltic Journal of Real Estate Economics and Construction Management, 3, 140-150. http://dx.doi.org/10.1515/bjreecm-2015-0014

Global Reporting Initiative. (2000). Sustainability Repointing Guidelines on Economic, Environmental and Social Performance. Boston.

Nikulina, A. Yu. (2016). Evaluation and Selection of investment solution for oil and gas development in the Arctic. Arctic: Ecology and Economy. Research and Information-Analytical Magazine, 2(22), 51-55.

Potravnyy, I. M., Gassiy, V. V., Chernogradsky, V. N., \& Postnikov A. V. (2016). Social 
responsibility of mining companies in the territory of traditional nature management as a basis for partnership between the government, business and indigenous peoples of the North. Arctic: Ecology and Economy. Research and Information-Analytical Magazine, 2(22), 56-63.

Schierenbeck, H., \& Seidel, E. (Eds.). (2000). Banken und Oekologie. Konzepte fuer die Umwelt. Frankfurt-am-Main: Gabler. 136 p.

Schmidt, F. P. (1999). Aspekte oekologischer Risiken im genossenschaftlicher Bankgesellschaft. Umweltwirtschaftsforum, 3, 27-29.

Silva, C. V. (1999). Umweltorientierung in der Sparkassenorganisation. Umweltwirtschaftsforum, $3,50-54$.

United Nations. (2011a). UNEP Finance Initiative: Positive Impact Manifesto. Retrieved from United Nations website http://www.unepfi.org/publications/

United Nations. (2011b). UNEP FI Guide to Banking \& Sustainability. Retrieved from United Nations website: http://www.unepfi.org/fileadmin/documents/guide_banking_statements.pdf

Viehohh, V., \& Theis, S. (Eds.). (1997). Die Macht der Banken / Ein Beitrag der Oekobank. Frankfurt-am-Main: Oekobank. 12 p.

Zaya, S. (2014). Government progress in green development. Mongolian Economy, 12, 9-12.

\section{AUTHORS' SHORT BIOGRAPHIES}

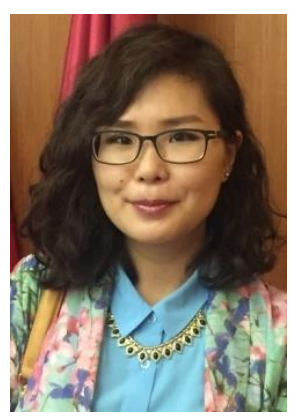

Khaliun Ganbat obtained the Master degree in Finance and Credits in 2013, and since 2014, has been studying for PhD in the Banking Department of Plekhanov Russian University of Economics. She has worked as a dealer in the Treasury Department in Capitron Bank in Mongolia. She had an internship in International Department of Trade and Development Bank of Mongolia from March 2013 to May 2013. Currently she is actively working on her research. She is an author of 15 research articles published in Russian and American journals. She has participated in international conferences in Mongolia, Russian Federation, the USA, and Thailand. Her research interests are investment activity of commercial banks, their participation in investment of ecological and socially oriented projects, "green" banking enhancing the method of giving a value to investment projects with the help of real options, banking riskmanagement.

Phone: +79295061206

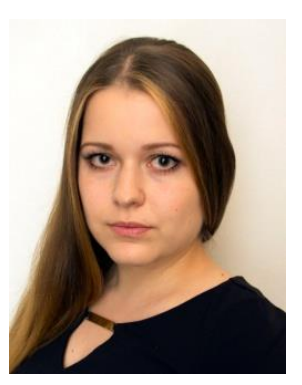

Inessa Popova is a graduate student with the Department of Project Management of Plekhanov Russian University of Economics in Moscow. She successfully completed the master's degree course in "Public management and administration" in 2015. She is an author of 5 scientific articles. She has participated in many international and Russian scientific-practical conferences.

The areas of her scientific interest are assessment of economic activity influence on environmental condition and social-economic development of the Arctic area of the Russian Federation, ecological and ethnological aspects of investments projects argumentation on the territories of traditional environmental management. She is a member of the Russian Society for Ecological Economics and Scientific Grants of Russian Foundation for Humanities (RFH).

Phone: +7 9055844486 


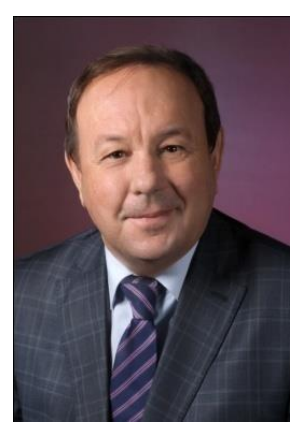

Ivan Potravnyy, Doctor of Economics, is a Professor with Plekhanov Russian University of Economics. He is the author of over 400 scientific articles, monographs, and textbooks in the field of environmental economics, sustainable development, methods of management of ecological-economic projects. He has participated in international projects and conferences in the field of "green" economy, environmental management in Germany, Switzerland, Latvia, Mongolia, China, Vietnam, Thailand, Ukraine, the Czech Republic etc. He has tutored 63 candidates and doctors of economic sciences in the field of environmental economics and regional economics. He is a member of the European and the Russian Society for Ecological Economics, Free Economic Society of Russia, and a member of the Expert Council under the government of the Russian Federation.

Phone: +79165408321 